\title{
Kiat-kiat Membangun Strategi Pembelajaran Emansipatoris pada Pendidikan Dasar Islam
}

\author{
Muhammad Arif Syihabuddin ${ }^{1}$ \\ ${ }^{1}$ Institut Keislaman Abdullah Faqih (INKAFA) Gresik \\ ${ }^{1}$ arifmuhammad599@gmail.com
}

\begin{abstract}
This article discusses about emancipatory education, the main focus is the strategy of building emancipatory education. Education has a close relationship with social change, both in the form of dynamics of individual development and social processes on a broader scale. This study of emancipatory education is important, because in this globalization era Education is one of the decisive aspects, especially in opening the way to liberation from poverty, ignorance and adversity. Emancipatory meaning is human liberation from fetters in the context of Education, this emancipatory idea is expected to be able to give new colors and changes to the process and implementation of Education which has been regarded as giving less freedom. The liberation paradigm is the main basis of emancipatory education. This liberation makes an education play a role in freeing students from ignorance, retardation, obedience and immorality. There are several efforts that must be made in building an emancipatory learning strategy on Islamic Education. First, shifting the focus of attention from religion to religiosity. Second, enter plurality. Third, emphasizing the formation of attitudes. Then there are three keys in the emancipatory Education model, namely: humanization, critical and democratic awareness.
\end{abstract}

Keywords: Emancipatory, Islamic Education, Learning Strategy

\begin{abstract}
Abstrak
Artikel ini mendiskusikan tentan pendidikan emansipatoris, fokus utamanya adalah strategi pembangunan pendidikan emansipatoris. Pendidikan mempunyai keterkaitan erat dengan perubahan sosial, baik berupa dinamika pengembangan individu maupun proses sosial dalam skala yang lebih luas. Kajian ini penting karena dalam era globalisasi ini pendidikan merupakan satu aspe yang menentukan, khususnya dalam membuka jalan kebebasan dari kemiskinan, ketidakpedulian dan kesengsaraan. Pembebasan dalam konteks ini berarti pembebasan manusia dari belenggu dalam pendidikan, ide pembebasan ini diharapkan mampu memberikan warna baru dan mengubah proses pelaksanaan pendidikan yang sejauh ini dinilai kurang memberikan kebebasan. Paradigma pembebasan merupakan basis utama pendidikan emansipatoris. Pembebasan ini membuat pendidikan berperan dalam pembebasan peserta didik dari ketidakpedulian, penghambatan, keterbelakangan, dan perilaku tidak bermoral. Ada beberapa usaha yang harus dilakukan dalam membangun sebuah strategi pembelajaran emansipatoris dalam pendidikan Islam. Pertama, perubahan fokus perhatian dari agama menuju religiusitas. Kedua, memasukkan aspek keragaman. Ketiga, menekankan
\end{abstract}


pembentukan sikap. Kemudian ketiga kunci itu dijadikan model dalam pendidikan emansipatoris antara lain humanisasi, kesadaran kritis dan demokratis.

Kata Kunci: Emansipatoris, Pendidikan Islam, Strategi Pembelajaran

\section{Pendahuluan}

Pendidikan merupakan asas utama kehidupan umat manusia. Pendidikan bisa dipahami sebagai sebuah proses pembentukan manusia menjadi sebenar-benarnya makhluk yang dipilih sebagai kholifatu fi al-ardl. Pendidikan dapat pula dipahami sebagai suatu proses yang harus dijalani oleh manusia dalam rangka mendapatkan sebuah kebenaran ilmiah. Dalam keanekaragaman pandangan terkait pendidikan, dapat ditemui beberapa kesamaan antara beberapa rumusan, yaitu rumusan pendidikan yang dinilai sebagai sebuah proses; karena melalui proses tersebut seseorang berusaha secara sengaja bertujuan membuat pertumbuhan dan perkembangan orang lain. Yang dimaksud adalah proses berupa kegiatan memberikan arahan kepada orang lain agar dapat berkembang sesuai dengan nilai-nilai dan norma-norma yang dianggap benar. ${ }^{1}$

Di saat arus globalisasi semakin kuat seperti sekarang ini, pendidikan memiliki peran yang lebih penting, paling tidak menjadi benteng pertahanan. Karena dengan derasnya arus globalisasi sedikit banyak memberikan dampak terhadap kondisi yang ada. Karena globalisasi ini dapat membawa pengaruh nilai-nilai dan budaya baru, bahkan kadang tidak sesuai dan bertentangan dengan nilai luhur, budaya dan kepribadian bangsa Indonesia. Jika tidak ada persiapan yang matang untuk menghadapi derasnya arus globalisasi, maka hal tersebut akan menjadi menakutkan karena dapat mengarahkan kepada sesuatu yang bernilai negatif. ${ }^{2}$

Berbagai bentuk dan konsep penyelenggaraan pendidikan telah banyak digagas oleh para ahli, di Indonesia misalnya, ada banyak program yang ditawarkan untuk kegiatan pendidikan, seperti kegiatan pendidikan yang dikemas dalam bentuk formal dan non-formal.

Perubahan sosial yang ada juga sangat terkait dengan kondisi pendidikan, perubahan tersebut bisa berupa proses sosial dan dinamika perkembangan individu dalam skala yang lebih luas. Azra mengutip pendapat Muhammad Abduh yang secara tegas menyatakan bahwa dalam melakukan sebuah perubahan, pendidikan bisa menjadi

\footnotetext{
1 Bashori Muchsin dkk., Pendidikan Islam Humanistik: Alternatif Pendidikan Pembebasan Anak (Bandung: Refika Aditama, 2010), 3.

${ }^{2}$ Mohammad Mustari, Manajemen Pendidikan (Jakarta: PT RajaGrafindo Persada, 2014), 229.
} 
alat yang paling ampuh, efektif dan efisien. ${ }^{3}$ Sudah barang tentu perubahan tersebut adalah dalam semua aspek, mulai dari kebodohan, kemiskinan dan keterpurukan. Selanjutnya Paulo Freire berpendapat bahwa dengan pendidikan perubahan dan pembebasan yang diupayakan dapat menjadi perubahan yang bersifat permanen. Dalam hal ini ada dua tahapan yang harus dilalui. Pertama, manusia harus mengetahui masa dan sadar atas pembebasan yang diupayakan terhadap mereka, serta melalui praksis mengubah keadaan tersebut. Kedua, tahap ini dibangun berdasar tahap yang pertama dan berupa proses tindakan kultural yang membebaskan. ${ }^{4}$

Di Indonesia sendiri, dalam ranah pemikiran dan gerakan sosial, Islam emansipatoris adalah terobosan yang baru. Gagasan ini melakukan konsensus makna baru terhadap pemahaman agama (teks) sebagai sistem makna dan nilai yang memihak kepada kaum lemah dan terpinggirkan. Isu-isu yang diangkat adalah isu-isu tentang ketidakadilan, keterbelakangan dan kemiskinan yang dihadapi masyarakat bawah. ${ }^{5}$ Dalam konteks pendidikan, gagasan ini diharapkan mampu memberi warna baru dan perubahan terhadap proses dan penyelenggaraan pendidikan yang selama ini dianggap kurang memberikan kebebasan.

Sebagai pelaku pendidikan, tentunya kita juga mempunyai tanggungjawab yang sama yaitu berperan aktif turut menyukseskan pendidikan. Terlebih kaitannya dengan pendidikan yang berbasis emansipatoris, sehingga cita-cita pendidikan dapat dicapai dengan penuh sesuai dengan ekspektasi masyarakat Indonesia.

\section{Metode Penelitian}

Jenis penelitian yang digunakan dalam tulisan ini tergolong dalam penelitian kepustakaan. ${ }^{6}$ Dengan begitu data yang digunakan dalam kajian ini berupa data kepustakaan untuk membahas problematika yang telah dirumuskan. Selanjutnya akan dianalisis melalui pendekatan content analysis. ${ }^{7}$

\footnotetext{
${ }^{3}$ Azyumardi Azra, Esai-Esai Intelektual Muslim dan Pendidikan Islam (Jakarta: Logos, 1999), 12-14.

${ }^{4}$ Dennis Collins, Paulo Freire: Kehidupan, Karya dan Pemikirannya (Yogyakarta: Pustaka Pelajar \& Komunitas Apiru, 1999), 39.

${ }^{5}$ Very Verdiyansyah, Islam Emansipatoris: Menafsir Agama Untuk Praksis Pembebasan (Jakarta: P3M, 2004), 176.

${ }^{6}$ Suharsimi Arikunto, Prosedur Penelitian: Suatu Pendekatan Praktek (Jakarta: Rineka Cipta, 1998), 1011.

${ }^{7}$ Lexy J. Moleong. Metodologi Penelitian Kualitatif (Bandung: PT. Remaja Rosdakarya, 2006), 220.
} 


\section{Paradigma Pendidikan Emansipatoris}

Paradigma emansipatoris merupakan sebuah paradigma pembebasan. Emansipatoris memiliki makna pembebasan, membebaskan umat manusia dari berbagai belenggu yang berupa belenggu ekonomi, sosial, politik dan belenggu-belenggu lainnya. Dalam konteks Pendidikan, belenggu yang ada adalah kebodohan dan keterpurukan umat manusia. Belenggu-belenggu ini yang harus diupayakan pembebeasannya. Para tokoh telah banyak memberikan pengaruh terhadap pemikiran tentang ide-ide pokok dan mendasar tentang Pendidikan Islam emansipatoris yang kemudian melahirkan prinsip-prinsip dasar paradigmatik pendidikan Islam emansipatoris. Pendidikan emansipatoris dapat dikatakan sebagai suatu Pendidikan yang berperan membebaskan peserta didik dari kebodohan, keterbelakangan, keterbelengguan, ketersesatan dan kemaksiatan. Jadi Pendidikan hadir sebagai 'penolong' dan pemberi 'jalan keluhuran' bagi peserta didik sehingga benar-benar terjadi perubahan positif-konstruktif dalam diri mereka. ${ }^{8}$

Berikut ini adalah prinsip dasar pengembangan Pendidikan emansipatoris:

1. Keterbukaan al-Quran. Tatkala al-Qur'an diposisikan sebagai sebuah kitab suci yang tertutup, maka hal ini memiliki konsekuensi. Pendidikan yang ada hanya akan memberikan pengajaran sikap agama yang legalistik, maksudnya adalah pendidikan akan berputar-putar pada aspek hukum ancaman atau sanksi saja, bahkan cenderung mencari kesalahan seseorang. Keterbukaan al-Quran yang dimaksudkan adalah dalam proses penafsiran yang berintegrasi dengan problem-problem sosial. Sehingga pendidikan tidak dinilai lagi kurang memberikan respon terhadap problem-problem sosial seperti tingginya angka putus sekolah, kasus-kasus korupsi, isu gender, kemiskinan dan lain sebagainya.

2. Keadilan. Prinsip keadilan (al-adalat) merupakan implikasi dari ketakwaan. Ide tentang keadilan merupakan prinsip dasar untuk memperlakukan orang lain dengan sama, adil dan tidak diskriminatif, baik dalam pengelolaan sumber daya ekonomi, politik, sosial budaya, pendidikan, dan penerapan hukum. ${ }^{9}$ Para nabi hadir sebagai bentuk dan langkah sistematis dalam rangka membebaskan kaumnya dari segala bentuk penindasan, ini berarti kehadiran para nabi adalah

\footnotetext{
${ }^{8}$ Mujamil Qomar, Manajemen Pendidikan Islam: Strategi Baru Pengelolaan Lembaga Pendidikan Islam (Jakarta: Erlangga, 2008), 209.

${ }^{9}$ Hendar Riyadi, Melampaui Pluralisme, Etika Al-Qur'an tentang Keragaman Agama (Jakarta: RM Books dan PSAP, 2007), 177-179.
} 
untuk menegakkan pondasi dari keadilan. Pendidikan di sini memiliki makna sebuah proses perubahan struktural dalam penghapusan eksploitasi manusia secara esensial dengan memberikan semangat kesederajatan dan keadilan sosial. Dalam prinsisp pendidikan Islam emansipatoris ini cenderung menghendaki adanya sebuah penghargaan terhadap kesamaan potensi paling sempurna yang dimiliki manusia, yaitu berupa akal.

3. Sejatinya agama yang diturunkan oleh Allah SWT adalah mementingkan sebuah transformasi sosial, yaitu pembebasan fisik, akal dan martabat kemanusiaan supaya dapat memberikan kesejahteraan kepada seluruh umat manusia. Oleh karena itu, agama seharusnya dapat dipahami secara produktif dan up to date dalam rangka pelepasaan ketergantungan umat manusia dari hegemoni tertentu. Dengan demikian, pendidikan harus mampu memberikan dampak positif terhadap manusia, agar manusia dapat terbebas dari hegemoni tertentu tersebut sehingga daya nalar dan kritik manusia tidak hilang.

4. Kemanusiaan. Prinsip dasar ini berupaya menghadirkan sebuah dimensi yang tidak melihat perbedaan apapun dari diri manusia dalam mengangkat harkat dan martabat. Jika melihat kembali sejarah penyebaran Islam pada mulanya adalah mempunyai misi untuk menegakkan keadilan dan tidak memandang latar belakang sosial. Namun sangat disayangkan, sejarah Islam yang merupakan kekuatan pembebas kemanusiaan lintas batas tersebut mengalami kemandegan analisis, yaitu berhenti pada sebuah titi yaitu agama untuk Tuhan. Sebagai dampaknya, tema-tema sosial jarang sekali ditemukan pembahasannya dalam pendidikan agama, sehingga menghilangkan jarak dengan manusia dalam realitas.

5. Pluralism. Pluralism harus dipahami sebagai pertalian sejati kebhinekaan dalam ikatan-ikatan keadaban (genuine engagement of diversities within the bound of civility). ${ }^{10}$ Agama Islam merupakan agama damai, ini terbukti dan dapat dilihat secara jelas dalam misi kenabian yang berupa kesejahteraan. Terdapat adagium yang mendukung praksisnya, yaitu menghindarkan kerusakan lebih diutamakan dari upaya menghadirkan kebaikan. Untuk itu Islam lebih mementingkan dan mengedepankan toleransi ketimbang konfrontasi, kendati posisinya adalah sebagai pihak yang kuat.

\footnotetext{
${ }^{10}$ Bhudy Munawar Rahman, Islam Pluralis (Jakarta: Paramadina, 2001), 31..
} 
6. Sensitifitas gender. Jika kita melihat pada berbagai sejarah tradisi dan budaya, kita akan menemukan berbagai tragedi yang mengerikan tentang perempuan. Misalnya pada peradaban Romawi dan Yunani, banyak sekali perempuan yang dijadikan sebagai budak. Perempuan di jazirah Arab pun demikian, bahkan kelahirannya disambut dengan penguburan hidup-hidup. Di Indonesia mitos kultural tentang rendahnya perempuan juga berkembang, yang meletakkan perempuan dengan suatu wilayah domestik. Hal tersebut berdampak pada pendidikan publik yang cenderung patriarkis (male dominated).

7. Non-diskriminatif. Aspek ini merupakan hambatan yang utama dalam kehidupan bermasyarakat yang berikutnya melahirkan bentuk penindasan dan ketidakadilan. Salah satu penyebab yang sering mengakibatkan adanya proses diskriminasi adalah adanya sebuah ekspresi kesombongan, baik kesombongan dalam bentuk intelektual, sosial, emosional, bahkan kesombongan keagamaan. Yang kemudian memberikan gambaran sebuah penghayatan eksistensi asma' Allah yang ada, hanya satu saja nama Allah yang dibreak down dalam kehidupan sehari-hari, yaitu nama mutakabbir.

Jika pemahaman tentang pendidikan adalah sebagai proses aktualisasi sifatsifat ilahiyah pada umat manusia, maka seharusnya kandungan yang ada pada asma mutakabbir harus diintegrasikan dalam kehidupan bermasyarakat dengan sebuah kesadaran, bahwa tidak ada unsur superioritas pada diri manusia atas manusia yang lain. Dari sini dapat dipahami bahwa pendidikan emansipatoris adalah konsepsi pendidikan yang berusaha memadukan antara teosentris, antroposentris dan kosmosentris dalam rangka untuk membebaskan umat manusia dari hegemoni-hegemoni tertentu atas dasar tauhid yang sebagai dogma revolusi. Dalam sebuah format pendidikan yang membebaskan, terdapat sebuah keleluasaan dalam kreatifitas berpikir peserta didik untuk mampu mengkritisi realitas sosial dengan kemurnian corak berpikir masing-masing individu.

Paradigma pendidikan Islam emansipatoris adalah sebuah paradigma yang memiliki hubungan erat dengan peranan pendidikan itu sendiri. Ada beberapa hal yang perlu diperhatikan dalam mengidentifikasi peranan pendidikan, yaitu: a) memasyarakatkan ideologi dan nilai-nilai sosio-kultural bangsa, b) mempersiapkan tenaga kerja untuk memerangi kemiskinan, kebodohan dan mendorong adanya perubahan sosial, c) meratakan kesempatan dan 
pendapatan. Peran yang pertama merupakan fungsi politis pendidikan dan dua peran lainnya merupakan fungsi ekonomi. ${ }^{11}$

\section{Kiat-kiat Membangun Strategi Pembelajaran Emansipatoris pada Pendidikan Dasar Islam}

Pendidikan anak di Indonesia sudah sering mendapat sorotan dari kalangan ahli pendidikan dan tokoh-tokoh agama. ${ }^{12}$ Pendidikan Islam yang dikembangkan mulai dari jenjang pendidikan dasar sampai jenjang pendidikan tinggi selama ini dirasa masih cenderung bersifat verbalistik, yang penekanannya pada aspek indoktrinisasi dan penanaman nilai-nilai ala kadarnya, tidak berupa penumbuhan daya kritis dan pengembangan intelektual peserta didik. Oleh karena sifatnya yang doktriner, maka perbuatan salah dianggap sebagai sesuatu yang ber"dosa" yang pelakunya diancam dengan neraka sebagai balasannya. Pendidikan yang demikian ini memang pada satu sisi dapat mendorong anak untuk berbuaat santun, tunduk pada sebuah perintah dan memiliki tingkah laku yang mulia, namun di sisi lain, penumbuhan daya kritis dan pengembangan intelektual anak akan menjadi terabaikan.

Dalam proses pembelajaran yang bertujuan untuk menciptakan generasi muslim yang emansipatoris kiranya ada beberapa hal yang perlu dipertimbangkan. Di antaranya adalah melakukan reorientasi pembelajaran pendidikan agama, dengan melakukan pergeseran titik pusat perhatian dari agama ke religiusitas. Dalam beragama bukan to have religion yang menentukan untuk harus dihargai dan diusahakan, melainkan being religion.

Kemudian memasukkan kemajemukan, terutama kemajemukan agama sebagai bagian dari sebuah proses dalam rangka memperkaya pengalaman beragama. Memang realitas kosmiknya sebuah kemajemukan adalah realita yang tidak dapat terbantahkan. Oleh sebab itu, hal penting yang perlu dikembangkan adalah sikap proaktif dengan cara mengembangkan rasa kesamaan dan saling pengertian, bukan hanya sekedar berdampingan dengan damai tetapi tidak ada saling pengertian.

Selanjutnya menekankan pada proses pembentukan sikap. Selama ini pendidika agama yang berlaangsung cenderung lebih memuat materi agama secara eksplisit tekstual. Pembelajarannya lebih pada memberikan ceramah, bukan memberikan bimbingan serta mengkondisikan peserta didik untuk menumbuhkembangkan potensi

\footnotetext{
${ }^{11}$ Zamroni, Paradigma Pendidikan Masa Depan (Yogyakarta: Bigraf Publishing, 2000), 2.

${ }^{12}$ Muchsin dkk., Pendidikan Islam, 42.
} 
diri. ${ }^{13}$ Pola ini sangat mudah dijumpai, bahkan pada lembaga pendidikan seperti pesantren. Pesantren yang dari awal merupakan lembaga pendidikan yang benar-benar mampu mencetak kader dan generasi muslim kaffah sampai saat ini pembelajarannya masih banyak cenderung eksplisit tekstual.

Pendidikan emansipatoris di samping efektif untuk membangun kemandirian berpikir peserta didik, juga sangat efektif dalam membangun sikap kritis serta pencerahan akal. Dampak yang luas dari pendidikan emansipatoris ini akan menumbuhkan learning society dan educational society. Learning society adalah sebuah bentuk masyarakat yang akan selalu siap untuk menjawab kebutuhannya masingmasing. Mereka tidak akan terlalu bergantung pada fasilitas atau ruang yang telah diberikan oleh negara, yang justru terkadang memberikan belenggu dan mengontrol kebebasan. Dalam menciptakan proses pembelajaran yang baik, guru atau pendidik harus mampu menempatkan dirinya sebagai sosok yang terlibat secara langsung dalam proses pembelajaran tersebut. Dalam arti seorang pendidik harus mampu mensejajarkan dirinya dengan komunitas yang berada pada proses itu secara total. Maxine Greene berpendapat bahwa untuk mencari gerak yang komunikatif dan kata yang ekspresif, seorang pendidik harus secara sadar mencoba untuk bergerak di antara dan merenungkan bersama-sama dengan peserta didik. Dia berkonsistensi dengan peserta didik serta membuka beberapa kemungkinan dalam cara pandang bersama peserta didik. $^{14}$

Pendidikan emansipatoris dipandang sebagai pendidikan yang pergerakannya menekankan perwujudan masyarakat yang adil dan demokratis. Masyarakat yang adil artinya bahwa dalam kehidupan suatu masyarakat tersebut tidak dijumpai sebuah kelompok yang dianggap lebih penting dan utama dibanding yang lain atau tidak memihak sebelah melainkan seimbang. Masyarakat demokratis artinya bentuk partisipasi dalam melaksanakan hak dan kewajiiban di dalam suatu masyarakat dalam tugas dan tanggung jawabnya sebagai warga masyarakat. Dalam konteks lingkungan sekolah, adanya interaksi mutualis antara peserta didik dengan pendidik, peserta didik dengan peserta didik lain, serta peserta didik dengan lingkungan seekolah itu sendiri.

Pendidikan emansipatoris pada dasarnya bertujuan untuk mengembangkan pemahaman dan pengalaman siswa tentang realitas, kesadaran emansipatoris, kesadaran politis, pemberdayaan dan berlangsungnya dialog murni. Dalam pendidikan

\footnotetext{
${ }^{13}$ Komarudin Hidayat, Wahyu di Langit Wahyu di Bumi (Jakarta: Paramadina, 2003), 126.

${ }^{14}$ Maxine Greene, Feeling Power: Emotions and Education (London: Routledge, 1999), 196.
} 
emansipatoris, baik guru maupun siswa adalah pembelajar. Ketika terjadi dialog antara keduanya, maka pemahaman dan pengalaman akan realitas dari kedua belah pihak pun berkembang.

Ada tiga kunci dalam model pendidikan emansipatoris, yaitu: humanisasi, kesadaran kritis dan demokratis. Humanisasi merupakan suatu upaya untuk memberdayakan pemahaman kritis antara guru dan siswa, untuk menciptakan manusia yang humanis diperlukan cinta, kerendahan hati, iman, kepercayaan, harapan, serta pemikiran kritis. Banyak orang yang pandai secara intelektual tetapi belum tentu ia mampu menjadi orang yang humanis bagi yang lain. Humanis lebih menekankan bagaimana manusia mampu berelasi dengan manusia yang lain.

Manusia yang merupakan makhluk homo educable (dapat mendidik dan dididik), memiliki potensi untuk menjadi subjek dan objek dalam pengembangan diri. Karena potensi diri manusia tidak dapat berkembaang taanpa adanya stimulus dari luar, misalnya seperti pendidikan, maka pendidikaan itu pun harus berpijak pada potensi manusia tersebut. Arti penting dari penekanan pada potensi manusia ini berarti memandang manusia sebagai makhluk yang mampu berpikir, memiliki kebebasan dalam memilih, sadar diri, memiliki norma dan berkebudayaan. ${ }^{15}$

Kesadaran kritis mempunyai makna bahwa orang belajar untuk menerima keadaan sosial, ekonomi dan politik yang bertolak belakang, kemudian melawan arus penindasan realistis. Mampu menjadi pemikir yang kritis perlu ada dialog dalam bentuk mempertanyakan sistem untuk memahami sebuah realitas. Sikap kritis adalah kemampuan individu untuk melihat kembali nilai-nilai yang diyakini selama ini. Kesadaran kritis terletak pada saat seseorang mampu menerima atau menolak realitas dalam hidupnya dan mampu mempertahankan. ${ }^{16}$ Kemudian pedagogik kritis adalah sebuah teori tentang pendidikan dan praktis pembelajaran yang dimodel untuk membangun kesadaran kritis yang sesuai dengan kondisi sosial. ${ }^{17}$

Secara historis, pemilihan istilah emansipatoris pada dasarnya tidak lepas dari pembacaan teori kritis yang berkembang di era kontemporer yang dikaitkan dengan penafsiran pendidikan secara kritis. Dalam hal ini, yang dimaksud dengan penafsiran pendidikan secara kritis mencakup dua dimensi: pertama, realitas material, yaitu model

\footnotetext{
${ }^{15}$ Indah Aminatuz Zuhriyah, "Misi Emansipatoris Penyelenggaraan Pendidikan Islam,” Jurnal Madrasah 04, no. 02 (2012), 259-278.

${ }^{16}$ William A. Smith, Conscientezacao: Tujuan Pendidikan Paulo Freire (Yogyakarta: Pustaka Pelajar, 2012), 31.

${ }^{17}$ Rakhmat Hidayat, Pedagogik Kritis: Sejarah, Perkembangan dan Pemikiran (Jakarta: Rajawali Pers, 2013), 6 .
} 
penafsiran pendidikan yang berupa mempertsnyakan terhadap ideologi hegemonik, yang bertolak pada realitas empirik. Yang kedua, adalah visi transformatif, adalah model penafsiran pendidikan yang memiliki komitmen pada perubahan struktur, maupun relasi hegemonik pada hubungan sang pemberi dan sang penerima narasi (pendidik-peseerta didik) maupun relasi politik (penguasa-rakyat). ${ }^{18}$

Dalam mengekspresikan diri, demokrasi menjadi kata kunci untuk memberikan kebebasan dalam sebuah proses pembelajaran, demokratis dirasa sangat perlu, namun harus diperhatikan akan adanya kesalahpahaman akan makna demokrasi itu sendiri. Jangan sampai kebebasan yang diartikan itu kebebasan yang tanpa batas. Melainkan kebebasan yang diberikan adalah kebebasan yang menghormati dan memahami kebebasan individu lain. Ini perlu ditanamkan dan benar-benar dijaga untuk dapat menghindari pemberian makna yang berlebihan.

Menciptakan suatu pembelajaran yang demokratis tidak hanya memberi kebebasan kepada peserta didik dalam mengungkapkan ide pemikirannya, tetapi juga perlu ada upaya untuk memberikan kesadaran bahwa setiap orang mempunyai ide dan pemikiran yang berbeda. Selain itu, upaya yang harus dilakukan adalah menciptakan iklim sekolah yang demokratis. Sekolah demokratis adalah sekolah yang membawa semangat demokratis dalam perencanaan, pengelolaan dan evaluasi penyelenggaraan pendidikan di sekolah. ${ }^{19}$

Agar hal tersebut dapat terwujud, dibutuhkan tenaga pendidik yang berwawasan dan memiliki kesadaran tentang sebuah keragaman, sadar akan kemajemukan kehidupan. Tenaga pendidik juga merupakan seorang tokoh yang digugu dan ditiru. Pendidik mestinya berada di depan dan sebagai contoh bagi peserta didiknya. Oleh sebab itu, seorang pendidik harus selalu berhati-hati dalam bersikap, harus menjaga segala tindak tanduknya dalam pembelajaran dan kesehariannya. ${ }^{20}$ Maka dengan demikan, segala bentuk upaya yang telah dilakukan dalam membangun pendidikan yang demokratis akan dapat terwujud.

Dari paparan di atas dapat dipahami bahwa pendidikan yang berposisi sebagai tonggak perubahan pada masyarakat seharusnya dapat diawali dengan reparadigmatisasi menuju arah pemberdayaan. Segala bentuk pluralisme, pembebasan, kritisisme dan

\footnotetext{
${ }^{18}$ Verdiyansyah, Islam Emansipatoris, xvii.

19 Dede Rosyada, Paradigm Pendidikan Demokratis: Sebuah Model Pelibatan Masyarakat dalam Penyelenggaraan Pendidikan (Jakarta: Kencana, 2007), 15.

${ }_{20}$ Nur Laili Fitriyah, "Membangun Pembelajaran Demokratis Berwawasan Multikultural," Jurnal Madrasah 04, no. 01 (2012), 50-60.
} 
keadilan mestinya dijadikan pegangan dalam pergerakannya. Usaha untuk memberikan perubahan terhadap masyarakat yang telah sangat melekat dengan modernitas bukanlah sesuatu yang mudah, akan tetapi membutuhkan sense of social construction yang memadai, seelain itu juga membutuhkan waktu yang cukup lama. Dan ini merupakan tugas bagi seluruh generasi penerus bangsa.

\section{Penutup}

Paradigma pembebasan merupakan dasar utama pendidikan emansipatoris. Pembebasan ini menjadikan suatu pendidikan berperan dalam membebaskan peserta didik dari kebodohan, keterbelakangan, keterbelengguan, ketersesatan dan kemaksiatan.

Ada beberapa upaya yang harus dilakukan membangun strategi pembelajaran emansipatoris pada pendidikan Islam. Pertama, melakukan pergeseran titik perhatian dari agama ke religiusitas. Kedua, memasukkan kemajemukan. Ketiga, menekankan pada pembentukan sikap. Kemudian terdapat tiga kunci dalam model pendidikan emansipatoris, yaitu: humanisasi, kesadaran kritis dan demokratis.

\section{Daftar Rujukan}

Arikunto, Suharsimi. Prosedur Penelitian: Suatu Pendekatan Praktek. Jakarta: Rineka Cipta, 1998.

Azra, Azyumardi. Esai-Esai Intelektual Muslim dan Pendidikan Islam. Jakarta: Logos, 1999.

Collins, Dennis. Paulo Freire: Kehidupan, Karya dan Pemikirannya. Yogyakarta: Pustaka Pelajar \& Komunitas Apiru, 1999.

Fitriyah, Nur Laili. "Membangun Pembelajaran Demokratis Berwawasan Multikultural." Madrasah 04, No. 01 (2012).

Greene, Maxine. Feeling Power: Emotions and Education. London: Routledge, 1999.

Hidayat, Komarudin. Wahyu di Langit Wahyu di Bumi. Jakarta: Paramadina, 2003.

Hidayat, Rakhmat. Pedagogik Kritis: Sejarah, Perkembangan dan Pemikiran,. Jakarta: Rajawali Pers, 2013.

Moleong, Lexy J. Metodologi Penelitian Kualitatif. Bandung: PT. Remaja Rosdakarya, 2006.

Muchsin, Bashori, dkk. Pendidikan Islam Humanistik: Alternatif Pendidikan Pembebasan Anak. Bandung: Refika Aditama, 2010.

Mustari, Mohammad. Manajemen Pendidikan. Jakarta: PT RajaGrafindo Persada, 2014. 
Qomar, Mujamil. Manajemen Pendidikan Islam: Strategi Baru Pengelolaan Lembaga Pendidikan Islam, . Jakarta: Erlangga, 2008.

Rahman, Budhy Munawar. Islam Pluralis. Jakarta: Paramadina, 2001.

Riyadi, Hendar. Melampaui Pluralisme, Etika al-Qur'an tentang Keragaman Agama. Jakarta: RM Books dan PSAP, 2007.

Rosyada, Dede. Paradigma Pendidikan Demokratis: Sebuah Model Pelibatan Masyarakat dalam Penyelenggaraan Pendidikan,. Jakarta: Kencana, 2007.

Smith, William A. Conscientezacao: Tujuan Pendidikan Paulo Freire. Yogyakarta: Pustaka Pelajar, 2012.

Verdiyansyah, Very. Islam Emansipatoris: Menafsir Agama untuk Praksis Pembebasan. Jakarta: P3M, 2004.

Zamroni. Paradigma Pendidikan Masa Depan. Yogyakarta: Bigraf Publishing, 2000.

Zuhriyah, Indah Aminatuz. "Misi Emansipatoris Penyelenggaraan Pendidikan Islam,." Madrasah 04, No. 02 (2012). 